\title{
ANALISIS PREDIKSI KEBANGKRUTAN (FINANCIAL DISTRESS) DENGAN PERBANDINGAN MODEL ALTMAN, ZMIJEWSKI DAN GROVER
}

\author{
M. Agus Sudrajat ${ }^{1)}$, Eka Wijayanti ${ }^{2}$ \\ Fakultas Ekonomi dan Bisnis Universitas PGRI Madiun \\ agus.sudrajat84@gmail.com ${ }^{1)}, \underline{\text { v.jaythoex@gmail.com }{ }^{2)}}$
}

\begin{abstract}
The purpose of this study is to analyze bankruptcy predictions (Financial Distress) with a Comparison of the Altman Model (Z-Score), Zmijewski (X-Score) and Grover (G-Score) (Empirical Study in Manufacturing Companies in the Basic Industrial and Chemical Sector Sectors registered in IDX 2015-2018). This study uses non-parametric statistical data analysis with Kruskal Wallis different test. The research sample is 37 companies manufacturing basic and chemical industrial sectors which are listed on the Indonesia Stock Exchange (IDX) for the 2015-2018 period. The data used in this study are secondary data derived from the company's financial statements. The research sample was selected by purposive sampling technique with predetermined criteria. Hypothesis test results showed there are differences in predictions between the Altman model (Z-Score), Zmijewski (X-Score) and Grover (G-Score) in predicting bankruptcy (financial distress) of manufacturing companies in the basic and chemical industry sectors listed on the Indonesia Stock Exchange period 2015-2018. The Grover (G-Score) model is the most accurate prediction model with an accuracy level of $85.14 \%$. While the Altman model (Z-Score) has an accuracy rate of $77.70 \%$ and the Zmijewski model (XScore) of $79.73 \%$.
\end{abstract}

Keywords: Financial Distress, Altman Model, Zmijewski Model and Grover Model.

\begin{abstract}
Abstrak
Tujuan dari penelitian ini adalah untuk menganalisis prediksi kebangkrutan (Financial Distress) dengan Perbandingan Model Altman (Z-Score), Zmijewski (X-Score) dan Grover (G-Score) (Studi Empiris Pada Perusahaan Manufaktur Sektor Industri Dasar dan Kimia yang terdaftar di BEI Tahun 2015-2018). Penelitian ini menggunakan.analisis data statistik non parametrik dengan uji beda Kruskal Wallis. Sampel penelitian adalah 37 perusahaan manufaktur sektor industri dasar dan kimia yang terdaftar di Bursa Efek Indonesia (BEI) periode 2015-2018. Data yang digunakan dalam penelitian ini yaitu data sekunder yang berasal dari laporan keuangan perusahaan. Sampel penelitian dipilih dengan teknik purposive sampling dengan kriteria yang telah ditetapkan. Hasil uji hipotesis menunjukkan terdapat perbedaan prediksi antara model Altman (ZScore), Zmijewski (X-Score) dan Grover (G-Score) dalam memprediksi kebangkrutan (financial distress) perusahaan manufaktur sektor industri dasar dan kimia yang terdaftar di Bursa Efek Indonesia periode 20152018. Model Grover (G-Score) menjadi model prediksi paling akurat dengan tingkat keakuratan mencapai 85,14\%. Sedangkan model Altman (Z-Score) memiliki tingkat akurasi sebesar 77,70\% dan model Zmijewski (X-Score) sebesar 79,73\%.
\end{abstract}

Kata Kunci: Financial Distress, Altman, Zmijewski, Grover

\section{PENDAHULUAN}

Financial Distress atau kesulitan keuangan yang juga dikenal sebagai "krisis keuangan", mengacu pada situasi ketika arus kas tidak cukup untuk mengkompensasi utang berjalan. Perusahaan yang terdaftar mengalami krisis keuangan atau kebangkrutan dapat mempengaruhi stabilitas seluruh pasar modal atau bahkan dapat menyebabkan kepanikan investor dan kerugian ekonomi, sehingga kerusakan pada pihak kepentingan pemegang saham, kreditur, investor, dan karyawan perusahaan bisa menjadi serius. Jika ada model peringatan krisis keuangan yang layak bagi perusahaan yang terdaftar, selama tahap awal terjadinya krisis keuangan, kepada manajer bisnis, penanggulangan dapat diadopsi lebih awal untuk mencegah perluasan kerusakan. Bagi investor, model peringatan krisis keuangan juga dapat 
memperkuat pasar modal untuk memberikan jaminan kepada investor yang mungkin tidak menyadari status operasi perusahaan. Oleh karena itu, model peringatan layak mampu mendeteksi masalah dari perusahaan yang terdaftar untuk mencegah kerugian yang signifikan dari investor (Cheng et al., 2018).

Saat ini di Indonesia banyak perusahaan yang mengalami kesulitan keuangan sehingga terjadi penurunan kinerja dan diprediksi akan bangkrut. Diantaranya terjadi pada perusahaan besar yang berskala multinasional dan disebabkan oleh jumlah hutang yang lebih besar dari total harta. Beberapa diantara entitas bisnis ada yang sudah menghilang dari pasar. Kemungkin tertekan secara finansial, atau dilikuidasi, atau mereka dapat diakuisisi oleh perusahaan lain.

Menurut Fitzpatrick dalam Tuvadaratragool (2013), hal ini berdampak buruk terhadap stakeholder, misalnya karyawan, kreditor bank, pemegang saham, komunitas, dan pemerintah karena cenderung menderita dari investasi mereka, apa pun peristiwa yang memicu hilangnya entitas. Mengingat bahwa kegagalan bisnis dapat menyebabkan trauma yang signifikan (yaitu biaya tinggi dan kerugian besar) bagi para pemangku kepentingan ini, prediksinya sangat menguntungkan. Ini memotivasi para peneliti untuk menemukan alat pendeteksi gejala yang tidak menguntungkan sebelum entitas menghilang.

Salah satu solusi yang dapat dilakukan untuk mengatasi kerugian tersebut adalah menarik investor baru untuk menanamkan modal. Investor sendiri beracuan dari annual report (laporan tahunan) dari perusahaan. Namun kenyataan bahwa perusahaan tersebut sedang mengalami masa sulit tidak bisa ditutup-tutupi karena data laporan keuangan dapat diakses di Bursa Efek Indonesia sebagai Pasar Modal. Sebagai salah satu perlindungan terhadap calon investor PT Bursa Efek Indonesi (BEI) resmi memberlakukan program ISuite atau pemberian tanda khusus atau "tato" kepada perusahaan tercatat yang bermasalah. Program diberlakukan untuk memberikan informasi dan kenyamanan kepada investor di pasar modal sebelum bertransaksi.

Bursa Efek Indonesia (BEI) menyatakan terhitung hingga Jumat, 28 Desember 2018 pukul 15.00 terdapat 35 perusahaan yang mendapatkan notasi khusus. Tak hanya satu notasi, bursa juga memberikan dua notasi khusus pada perusahaan yang bermasalah. Perusahaan yang diberi tanda khusus tersebut nantinya bisa dilihat dalam website resmi BEI pada kolom notasi khusus. Mengutip laman resmi BEI, ada tujuh notasi khusus yang diberlakukan BEI. Setiap notasi khusus memiliki deskripsi masalah yang dialami oleh perseroan. Untuk tanda B, bermakna perusahaan sedang dalam permohonan pernyataan pailit. Untuk tanda M, mempunyai makna adanya permohonan Penundaan Kewajiban Pembayaran Utang (PKPU) pada perusahaan tersebut. Untuk tanda $S$, artinya laporan keuangan terakhir perusahaan menunjukkan tidak ada pendapatan usaha. Selanjutnya, E yang bermakna laporan keuangan terakhir menunjukkan ekuitas negative dan A yang bermakna adanya Opini Tidak Wajar (Adverse) dari Akuntan Publik (AP). Sementara itu untuk tanda $\mathrm{D}$, bermakna adanya opini tidak menyatakan pendapat (disclaimer) dari akuntan publik, dan L yang bermakna perusahaan tercatat belum 
menyampaikan laporan keuangan (www.cnnindonesia.com).

Penelitian yang dilakukan oleh Wulandari dkk. (2014) menyatakan bahwa krisis keuangan yang kemungkinan terjadi dalam sebuah perusahaan dapat diprediksi dengan model Altman, Springate, Ohlson, Fulmer dan Zmijewski. Namun berbeda dari model tersebut diatas, krisis keuangan yang kemungkinan terjadi pada perusahaan tidak dapat diprediksi dengan model CAScore. Sedangkan jika dibandingkan diantara model prediksi diatas diketahui bahwa model Ohlson mampu memprediksi secara efektif dan menjadi satu-satunya model dengan hasil paling efektif dan akurat untuk memprediksi krisis keuangan yang kemudian berpotensi terhadap kebangkrutan pada suatu perusahaan.

Penelitian lain yang dilakukan oleh Ambarwati dkk. (2017) menunjukkan bahwa rasio keuangan sangat berpengaruh dalam memprediksi krisis keuangan karena kategori yang menjadi tolak ukur perusahaan disebut bangkrut dan tidak bangkrut itu berbeda satu diantara yang lainnya. Hal ini memyebabkan hasil dari perhitungan model Altman, Springate, Zmijewski dan Fulmer menjadi berbeda. Berdasarkan uraian yang telah dijabarkan, penulis tertarik untuk melakukan penelitian dengan mengangkat permasalahan tersebut melalui judul "Analisis Prediksi Kebangkrutan (Financial Distress) dengan Perbandingan Model Altman (ZScore), Zmijewski (X-Score) dan Grover (G-Score)".

\section{KAJIAN TEORI DAN PENGEMBANGAN HIPOTESA} Kajian Teori

Analisis Laporan Keuangan
Menurut Subramanyam \& Wild, (2014) analisis laporan keuangan (financial statement analysis) adalah aplikasi dari alat dan teknik analitis untuk laporan keuangan bertujuan umum dan data-data yang berkaitan untuk menghasilkan estimasi dan kesimpulan yang bermanfaat dalam analisis bisnis. Analisis bisnis (business analysis) merupakan proses evaluasi prospek ekonomi dan risiko perusahaan.

Menurut Subramanyam \& Wild dalam Al Ali et al. (2018) berpendapat bahwa analisis keuangan menggunakan rasio keuangan adalah alat yang sangat berguna yang secara signifikan membantu pengambilan keputusan bisnis dan membedakan area yang lemah dan kuat dalam suatu perusahaan.

\section{Teori Sinyal (Signaling Theory)}

Menurut Houston dalam Kartikasari (2018), signaling theory merupakan keadaan dimana setiap individu (pihak manajer ataupun investor) berlaku hal yang sama (informasi) yaitu tentang prospek suatu perusahaan.Hal ini disebut dengan informasi simetri. Namun pada kenyataannya seringkali informasi yang dimiliki oleh manager lebih besar dari yang didapatkan oleh investor luar. Hal ini disebut dengan informasi asimetri dan berpengaruh besar pada tingkat keoptimalan dari struktur modal. Teori ini mengemukakan pengguna laporan keuangan semestinya mendapatkan sinyal dari perusahaan. berupa informasi mengenai manajemen (promosi) atau informasi lain yang dapat membuat pengguna laporan keuangan perusahaan benefit dan lebih bagus daripada perusahaan sejenis yang lain dan informasi tersebut dicantumkan dalam laporan keuangan tahunan perusahaan. 
Kesimpulannya dengan adanya prospek terbaik perusahaan tidak menentukan pilihan untuk melakukan pembiayaan pada penawaran saham baru, sedangkan dengan prospek terburuk perusahaan memiliki minat tinggi untuk membiayai ekuitas dari luar. Singkatnya pengumuman penawaran saham umumnya diambil sebagai sinyal bahwa prospek perusahaan seperti yang dilihat oleh manajemennya sendiri tidak baik, sebaliknya, penawaran utang dianggap sebagai sinyal positif (Koh et al., 2014).

\section{Kesulitan Keuangan}

$$
\text { Menurut Ghosh (2017), }
$$

kebangkrutan adalah teka-teki yang coba dihindari oleh perusahaan, para analis suka mengukur dan menemukan kesulitan untuk memprediksi secara umum. Potensi bahaya terletak pada aspek-aspek seperti kualitas aset yang buruk dan kapitalisasi yang lemah, terbukti dalam peristiwa historis lainnya. Menurut Timothy dalam Odibi et al. (2015), kebangkrutan adalah proses hukum di mana seseorang tidak dapat membayar petisi tagihan mereka. Ini adalah proses yang sah di mana perusahaan atau individu tidak likuid diberhentikan dari total kewajiban untuk kewajibannya dengan membuat pengaturan izin pengadilan untuk penyelesaian sebagian mereka.

Secara umum, krisis keuangan disebut sebuah perusahaan yang memiliki arus kas tidak mencukupi untuk membayar utangnya. Dalam analisis teoritis, krisis keuangan memiliki derajat yang berbeda, di mana krisis keuangan ringan mungkin melibatkan kesulitan sementara dalam arus kas, dan krisis keuangan yang serius dapat melibatkan kegagalan perusahaan atau kebangkrutan. Ketika sebuah perusahaan berada dalam krisis keuangan, mungkin mengalami perubahan dinamis antara kedua ujung ekstrim ini. Krisis keuangan sering didefinisikan sebagai beberapa situasi, dan situasi seperti itu jelas menggambarkan kesulitan keuangan seperti kebangkrutan hukum (Cheng et al., 2018).

Menurut Brigham dan Gapenski dalam Priambodo (2017), ada beberapa definisi kesulitan keuangan, sesuai tipenya, yaitu economic failure, business failure, technical insolvency, insolvency in bankruptcy dan legal bankruptcy. Menurut Koh et al. (2014), nilai intrinsik perusahaan adalah nilai sekarang dari arus kas bebas masa depan yang diharapkan. Ada banyak faktor yang dapat menyebabkan nilai ini menurun. Faktorfaktor ini termasuk kondisi ekonomi umum, tren industri, dan masalah khusus perusahaan seperti selera konsumen yang berubah, teknologi usang, dan perubahan demografi di lokasi ritel yang ada. Faktor keuangan, seperti terlalu banyak hutang dan kenaikan suku bunga yang tidak terduga, juga dapat menyebabkan kesulitan keuangan yang mengakibatkan terjadinya kegagalan dalam bisnis.

Lebih lanjut, studi kasus menunjukkan bahwa kesulitan keuangan biasanya merupakan hasil dari serangkaian rangkaian, kesalahan penilaian, dan kelemahan yang saling terkait yang dapat dikaitkan secara langsung atau tidak langsung dengan manajemen. Tanda-tanda potensi kesulitan keuangan umumnya terbukti dalam analisis rasio jauh sebelum perusahaan benar-benar gagal, dan hasil penelitian menggunakan analisis rasio untuk memprediksi probabilitas bahwa perusahaan tertentu akan bangkrut. Analisis keuangan terus mencari cara untuk menilai kemungkinan perusahaan bangkrut (Koh et al., 2014). 
Kesulitan keuangan perusahaan dapat dipicu oleh faktor internal dan eksternal. Faktor internal dapat muncul dari manajemen yang tidak efisien yang akan mempengaruhi kinerja keuangan dan pengelolaan aset perusahaan dan sebagai hasilnya pendapatan yang dihasilkan tidak mencakup biaya. Faktor eksternal dapat berasal dari perubahan kondisi ekonomi di mana perusahaan beroperasi seperti inflasi, peraturan baru dan sebagainya (Al Ali et al., 2018). Jauch \& Glueck dalam Peter \& Yoseph (2011), faktor penyebab terjadinya kesulitan keuangan adalah:

1. Faktor Umum

\section{a. Sektor Umum}

Terjadinya kenaikan dan penurunan harga barang dan jasa, suku bunga, kebijakan keuangan penurunan dan penilaian kembali mata uang asing dan penambahan dan pengurangan volume perdagangan luar negeri.

b. Sektor Sosial

Terjadinya perubahan perilaku masyarakat yang berpengaruh terhadap permintaan produk dan jasa serta adanya konflik.

c. Teknologi

Terjadinya peningkatan biaya pelaksanaan dan pemeliharaan akibat penggunaan teknologi informasi oleh manajemen yang tidak direncanakan.

d. Sektor Pemerintah

Terjadinya perubahan
kebijakan pemerintah
mengenai tarif ekspor impor
dan peraturan baru perundang-
undangan perbankan atau
tenaga kerja dll.

2. Faktor Eksternal Perusahaan a. Faktor Pelanggan/Konsumen
Terjadinya perubahan selera konsumen akan barang dan jasa.

b. Faktor Kreditur

Terjadinya kehilangan

kepercayaan kreditur untuk memberikan pinjaman terhadap suatu perusahaan.

c. Faktor Pesaing Terjadinya penurunan kualitas pelayanan, produk dan jasa oleh perusahaan yang memicu pelanggan beralih ke pesaing.

3. Faktor Internal Perusahaan

a. Terjadinya penunggakan pembayaran oleh nasabah akibat nilai kredit yang terlalu besar dan seringkali tidak sanggup melunasi.

b. Terjadinya kecurangan dan penyalahgunaan wewenang oleh manajer puncak dan karyawan yang menyebabkan penurunan keuangan perusahaan (rugi).

c. Terjadinya manajemen yang tidak efisien sebagai akibat dari minimnya pengalaman,kemampuan dan keterampilan dari bagian manajemen.

\section{Model Prediksi Kesulitan Keuangan Model Altman (Z-score)}

Menurut Balcaen \& Ooghe dalam Basoda \& Celik (2018), Altman pada tahun 1968 mengembangkan model analisis multivariat statistik, analisis diskriminan berganda (MDA), dan menghargai model Z-Score sebagai kontribusinya untuk penelitian pada perusahaan yang gagal. MDA mencoba membuat kombinasi sifat linier atau kuadrat yang paling membedakan kelompok. Model ini telah selama 
bertahun-tahun menjadi ciri penelitian kebangkrutan dan banyak dari model yang terakhir didasarkan pada model Altman. Altman sendiri menyesuaikan model Zskornya pada tahun 1977 menjadi model Zeta yang lebih baik. Model Altman mendominasi literatur tentang penelitian kebangkrutan hingga 1980-an ketika itu menurun, tetapi ada tetap metode standar yang diterima yang sering digunakan sebagai metode dasar untuk studi perbandingan melalui rumus:

$\mathrm{Z}$-Score $=6,56 \mathrm{X} 1+3,26 \mathrm{X} 2+6,72 \mathrm{X} 3+$

\section{$1,05 X 4$}

Keterangan:

$\mathrm{X} 1=$ Working Capital/Total Asset

$\mathrm{X} 2$ = Retained Earning/Total Assets

$\mathrm{X} 3$ = Earning Before Interest and

Taxes/Total Aset

X4 = Market Value of Equity/Book Value of Debt

Sumber: Widiyawati dkk. (2015)

Jika nilai Z-Score lebih besar dari 2,60, maka perusahaan dikategorikan sebagai perusahaan sehat. Jika nilai ZScore yang berada diantara 1,10 dan 2,60, maka perusahaan berada pada grey area (area kelabu) yang berarti perusahaan bisa berpotensi bangkrut atau tidak bangkrut. Jika nilai Z-Score lebih kecil dari 1,10, maka perusahaan berpotensi bangkrut.

\section{Model Zmijewski (X-Score)}

Menurut Al Ali et al. (2018), model zmijewski $\mathrm{x}$-score adalah salah satu model yang paling umum digunakan untuk mengukur kesulitan keuangan perusahaan. Zmijewski menggunakan data dari 40 perusahaan industri yang bangkrut dan 800 yang tidak bangkrut selama periode 1972-1978 untuk mengembangkan model skor-X. Zmijewski mengklaim bahwa model tersebut mencapai tingkat akurasi 99\% dalam menentukan kebangkrutan perusahaan dua tahun sebelum peristiwa kebangkrutan mereka melalui rumus:

$\mathrm{X}$-Score $=-4,3-4,5 \times 1+5,7 \times 2-$ $0,004 X 3$

Keterangan:

$\mathrm{X} 1=$ ROA (Return On Assets)

$\mathrm{X} 2$ = Leverage (Debt Ratio)

$\mathrm{X} 3=$ Likuiditas (Current Ratio)

Sumber: Prihantini dan Sari (2013)

Jika nilai $X$-Score lebih kecil dari 0, maka perusahaan dikategorikan sebagai perusahaan sehat. Sedangkan jika nilai $X$ Score lebih besar dari 0, maka perusahaan berpotensi bangkrut.

\section{Model Grover (G-Score)}

Menurut Grover dalam Manousaridis (2017), model grover adalah model yang dihasilkan dengan melakukan desain ulang dan penilaian ulang terhadap Model Altman Z-Score. Menurut Prihatini dan Sari dalam Ambarwati dkk. (2017), Jeffrey S. Grover menggunakan sampel sesuai dengan model Altman Z-score pada tahun 1968, dengan menambahkan tiga belas rasio keuangan baru. Sampel yang digunakan sebanyak 70 perusahaan dengan 35 perusahaan yang bangkrut dan 35 perusahaan yang tidak bangkrut pada tahun 1982 sampai 1996. Grover menghasilkan fungsi sebagai berikut:

G-Score $=1,650 \times 1+3,404 \times 3-$ 0,016ROA + 0,057

Keterangan:

$\mathrm{X} 1$ = Working Capital/Total assets

$\mathrm{X} 3$ = Earnings Before Interest and Taxes/Total Assets

$\mathrm{ROA}=$ Net Income/Total Assets

Sumber: Prihantini dan Sari (2013)

Jika nilai $G$-Score kurang atau sama dengan 0,01, maka perusahaan dikategorikan sebagai perusahaan tidak 
bangkrut. Sedangkan jika nilai G-Score lebih besar dari 0,02 maka perusahaan dikategorikan bangkrut.

\section{Hipotesa}

Peneliti diharuskan menguasai seluruh teori ilmiah sebagai dasar argumentasi dalam menyusun kerangka berpikir yang menghasilkan hipotesis (Sugiyono, 2016).

$\mathrm{H}_{1}$ : Terdapat perbedaan prediksi antara model Altman (Z-Score), Zmijewski (X-Score) dan Grover (GScore) dalam memprediksi kebangkrutan (financial

distress)perusahaan manufaktur sektor industri dasar dan kimia yang terdaftar di Bursa Efek Indonesia

periode 2015-2018.

\section{METODE PENELITIAN}

Penelitian ini merupakan jenis penelitian kuantitatif yang dilakukan berdasarkan data laporan keuangan perusahaan manufaktur dan diperoleh dari situs resmi Bursa Efek Indonesia www.idx.com. Populasi dalam penelitian ini adalah perusahaan manufaktur yang terdaftar di Bursa Efek Indonesia (BEI) selama empat periode dari tahun 20152018 sebanyak 168 perusahaaan. Pengambilan sampel menggunakan teknik purposive sampling. Purposive sampling merupakan teknik penentuan sampel dengan pertimbangan tertentu (Sugiyono, 2016). Adapun kriteria yang ditentukan dalam pengambilan sampel sebagai berikut :

\section{Tabel 1 Proses Seleksi Sampel}

\begin{tabular}{clc}
\hline No & Kriteria & Jumlah \\
\hline 1 & $\begin{array}{l}\text { Jumlah Perusahaan Manufaktur yang } \\
\text { terdaftar di BEI }\end{array}$ & 168 \\
\hline 2 & $\begin{array}{l}\text { Perusahaan yang bukan merupakan sektor } \\
\text { industri dasar dan kimia }\end{array}$ & $(97)$ \\
\hline 3 & $\begin{array}{l}\text { Sektor industri dasar dan kimia yang } \\
\text { dikeluarkan karena: }\end{array}$ & \\
\hline & Data tidak lengkap & $(19)$ \\
\hline
\end{tabular}

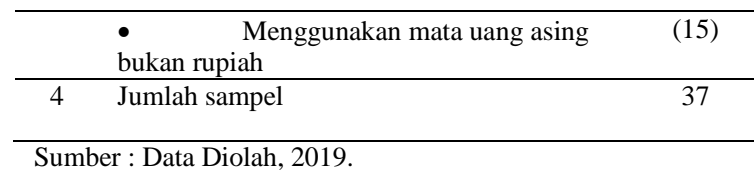

Selanjutnya

perusahaan manufaktur sektor dasar dan kimia yang digunakan sebagai sampel tersebut diketagorikan menjadi dua, yaitu:

1. Perusahaan yang diprediksi berpotensi mengalami kebangkrutan dikategorikan sebagai perusahaan distress dengan kriteria memiliki laba bersih negatif atau rugi dalam 2 tahun berturut-turut.

2. Perusahaan yang diprediksi tidak berpotensi mengalami kebangkrutan dikategorikan sebagai perusahaan non-distress dengan kriteria memiliki laba bersih positif dalam 2 tahun berturut-turut.

Dalam penelitian ini, pengumpulan data dilakukan dengan teknik dokumentasi. Metode dokumentasi adalah mencari data mengenai catatan peristiwa yang sudah berlalu dan hal-hal atau variable. Misalnya catatan harian, sejarah kehidupan (life histories), cerita, biografi, peraturan dan kebijakan. Penelitian ini menggunakan Uji Beda (Kruskal Wallis) dengan perhitungan IBM SPSS (Statistical Product and Service Solutions) versi 22 for Windows. Sedangkan teknik analisis data dalam penelitian ini adalah sebagai berikut:

\section{Statistik Deskriptif}

Menurut Sugiyono (2016), statistik deskriptif adalah statistik yang digunakan untuk menganalisis data dengan cara mendeskripsikan atau menggambarkan data yang telah terkumpul sebagaimana adanya tanpa bermaksud membuat kesimpulan berlaku untuk umum atau generalisasi. Sedangkan menurut Ghozali 
(2016), statistik deskriptif memberikan gambaran atau deskripsi suatu data yang dilihat dari nilai rata-rata (mean), standart deviasi, varian, maksimum, minimum, sum, range, kurtois dan skewness (kemenangan distribusi).

\section{Uji Normalitas}

Menurut Sugiyanto dalam Kartikasari (2018), dalam pengujian hipotesis dapat terjadi dua kemungkinan yaitu data normal dan data tidak normal. Dan untuk mengetahuinya apakah data tersebut normal atau tidaknya, penguji diharuskan melakukan pengujian kenormalannya menggunakan uji normalitas data dan menganalisis probabilitasnya. Data diasumsikan normal jika nilai probabilitasnya > 0,05 . Sebaliknya, jika nilai probabilitasnya < 0,05 maka data dikatakan tidak normal karena didak memenuhi asumsi kenormalannya maka pengujian dilakukan menggunakan Uji Kolmogorof Smirnov.

\section{Uji Hipotesis}

Menurut Santoso dalam Kartikasari (2018), dalam penelitian yang bertujuan untuk membandingkan atau mengetahui ada tidaknya perbedaan pada lebih dari dua sampel digunakan Uji Beda (One Way Anova). Selanjutnya jika hasil uji normalitas menunjukan adanya data yang tidak berdistribusi dengan normal, maka engujian hipotesis menggunakan uji Kruskall-Wallis. Uji Kruskal-Wallis (Kruskal-Wallis one-way analysis of variance by rank) merupakan teknik statistik non parametik yang digunakan untuk menguji hipotesis awal bahwa beberapa contoh berasal dari populasi yang sama/identik.

Sedangkan untuk tingkat akurasi menggunakan perhitungan sendiri. Dalam penelitian ini tingkat akurasi dari ketiga model yaitu model altman (z-score), zmijewski (x-score) dan grover (g-score) dihitung untuk mengetahui jumlah prediksi benar dan salah dari setiap model. Selanjutnya hasil prediksi dibandingkan untuk mengetahui model prediksi manakah yang paling akurat dalam memprediksikan kebangkrutan. Menurut Hasanah dalam Meiliawati dan Isharijadi (2016), tingkat akurasi dihitung untuk mengetahui jumlah prediksi benar dengan cara berikut:

Tingkat Akurasi $=($ Jumlah prediksi benar / Jumlah Sampel) x 100\%

Selain tingkat akurasi dari setiap model yang digunakan untuk memprediksi kebangkrutan, pertimbangan lain adalah tingkat eror-nya. Eror dibagi dua jenis, yaitu Type I dan Type II. Type I eror adalah kesalahan dari sampel perusahaan yang diprediksi tidak bangkrut tetapi bangkrut pada kenyataannya. Sedangkan kesalahan sampel perusahaan yang diprediksi bangkrut tetapi tidak bangkrut pada kenyataannya disebut Type II eror. Tingkat eror dihitung dengan cara sebagai berikut:

Type I Eror = (Jumlah kesalahan Type I / Jumlah Sampel) x $100 \%$.

Type II Eror = (Jumlah kesalahan Type II / Jumlah Sampel) x $100 \%$.

\section{HASIL DAN PEMBAHASAN}

Hasil Statistik Deskriptif

Tabel 2. Descriptive Statistics

\begin{tabular}{llllll}
\hline & $\mathrm{N}$ & Min & Max & Mean & Std. Deviation \\
\hline Z-Score & 148 & -13.83930 & 50.55217 & 2.2899132 & 5.27801826 \\
X-Score & 148 & -4.26795 & 4.45068 & -1.7245974 & 1.57680782 \\
G-Score & 148 & -2.55017 & 2.58811 & .4829496 & .65219196 \\
Valid N & 148 & & & & \\
(listwise) & 148 & & & \\
Sumber : Data Diolah, 2019.
\end{tabular}

Dari tabel 2 diatas diketahui bahwa model Altman (Z-Score) memiliki nilai min sebesar $-13,83930$, nilai max sebesar 50,55217, nilai mean sebesar 2,2899132 dan nilai standar deviasi sebesar 
5,27801826. Model Zmijewski (X-Score) memiliki nilai min sebesar $-4,26795$, nilai max sebesar 4,45068, nilai mean sebesar 1,7245974 dan standar deviasi 1,57680782. Model Grover (G-Score) memiliki nilai $\min$ sebesar $-2,55017$, nilai max sebesar 2,58811, nilai mean sebesar 0,4829496 dan standar deviasi 0,65219196 .

Hasil Uji Normalitas

Tabel 3. One-Sample Kolmogorov-Smirnov Test Berdasarkan nilai out put uji \begin{tabular}{lllll}
\hline & Z-Score & X-Score & G-Score & potensi kebangkrutan pada perusahaan \\
\hline $\mathrm{N}$ & 148 & 148 & 148 & manufaktur
\end{tabular}

$\begin{array}{llccc}\begin{array}{l}\text { Normal } \\ \text { Parameters }^{\mathrm{a}, \mathrm{b}}\end{array} & \text { Mean } & 2.2899132 & -1.7245974 & .4829496 \\ & \text { Std. Deviation } & 5.27801826 & 1.57680782 & .6521919 \\ \begin{array}{l}\text { Most Extreme } \\ \text { Differences }\end{array} & \text { Absolute } & .207 & .063 & .087 \\ & \text { Positive } & .167 & .063 & .049 \\ & \text { Negative } & -.207 & -.053 & -.087 \\ & & & & .087\end{array}$

$\begin{array}{llll}\text { Test Statistic } & .207 & .063 & .087\end{array}$

$\begin{array}{llll}\text { Asymp. Sig. (2-tailed) } \quad .000^{c} & .200^{\mathrm{c}, \mathrm{d}} & .008^{\mathrm{c}}\end{array}$

Sumber : Data Diolah, 2019.

Berdasarkan tabel 3 diatas dapat diketahui bahwa Model Altman (Z-Score) memiliki. nilai signifikasi $0,000<0,05$ yang berarti data tidak terdistribusi dengan normal, Model Zmijewski (XScore) 0,200 memiliki nilai signifikasi $0,200>0,05$ yang berarti data terdistribusi dengan normal dan Model Grover 0,008 < 0,05 yang berarti data tidak terdistribusi dengan normal. Dari ketiga model prediksi tersebut hanya terdapat 2 model prediksi yang memiliki nilai < Asymp. Sig. atau < 0,05, maka untuk uji selanjutnya memakai uji hipotesis non parametik yaitu uji Kruskal-Wallis.

\section{Hasil Uji Hipotesis}

\section{Tabel 4. Kruskal-Wallis Test}

\begin{tabular}{llll}
\hline Model Prediksi Kebangkrutan & N & Mean Rank \\
\hline Prediksi & Altman (Z-Score) & 148 & 315.90 \\
& Zmijewski (X-Score) & 148 & 105.96 \\
\hline
\end{tabular}

\begin{tabular}{ccc}
\hline Grover (G-Score) & 148 & 245.64 \\
Total & 444 & \\
\hline Sumber : Data Diolah, 2019. &
\end{tabular}

Tabel 5. Test Statistics ${ }^{\mathrm{a}, \mathrm{b}}$

\begin{tabular}{ll}
\hline & Prediksi \\
\hline Chi-Square & 205.308 \\
Df & 2 \\
Asymp. Sig. & .000 \\
\hline Sumber : Data Diolah, 2019. &
\end{tabular}

a. Kruskal Wallis Test

b. Grouping Variable Model kebangkrutan kimia dilakukan untuk melihat perbedaan prediksi antara model Altman (Z-Score), Grover (G-Score) dalam memprediksi kebangkrutan (financial distress). Data dikatakan tidak memiliki perbedaan prediksi antara model Altman (Z-Score), model Zmijewski (X-Score) dan model Grover (G-Score) dalam memprediksi kebangkrutan (financial distress) jika nilai Asymp. Sig. lebih dari 0.05 (Asymp. Sig $>0.05)$ dan sebaliknya dikatakan terdapat prediksi antara model Altman (Z-Score), model Zmijewski (X-Score) dan model Grover (G-Score) dalam memprediksi kebangkrutan (financial distress) jika nilai Asymp. Sig. kurang dari 0.05 (Asymp. Sig. < 0.05). Berdasarkan output uji Kruskal-Wallis diatas dapat dilihat bahwa nilai Asymp. Sig. kurang dari 0.05 yaitu 0.00 (Asymp. Sig. < 0.05) sehingga $\mathrm{H}_{0}$ ditolak dan $\mathrm{H}_{1}$ yang menyatakan bahwa terdapat perbedaan prediksi antara model Altman (Z-Score), model Zmijewski (XScore) dan model Grover (G-Score) dalam memprediksi kebangkrutan (financial distress) diterima. Sehingga dapat disimpulkan bahwa terdapat perbedaan prediksi antara model Altman (Z-Score), model Zmijewski (X-Score) dan model Grover (G-Score) dalam memprediksi kebangkrutan (financial distress) perusahaan manufaktur sektor industri dasar dan kimia yang terdaftar di Bursa Efek Indonesia periode 2015-2018. 
Berikut ini hasil rekapitulasi perhitungan dari ketiga model beserta hasil dan tingkat akurasi yang disajikan dalam bentuk tabel, seperti:

Tabel 5. Perhitungan Keakuratan Prediksi Model Altman

\begin{tabular}{|c|c|c|c|c|}
\hline \multirow[b]{2}{*}{ Tahun } & \multicolumn{3}{|c|}{ Hasil Prediksi } & \multirow[b]{2}{*}{ Sampel } \\
\hline & Benar & $\begin{array}{l}\text { Type I } \\
\text { Error }\end{array}$ & $\begin{array}{c}\text { Type II } \\
\text { Error }\end{array}$ & \\
\hline 2015 & 30 & 7 & 0 & 37 \\
\hline 2016 & 28 & 7 & 2 & 37 \\
\hline 2017 & 26 & 8 & 3 & 37 \\
\hline 2018 & 31 & 5 & 1 & 37 \\
\hline Jumlah & 115 & 27 & 6 & 148 \\
\hline
\end{tabular}

\begin{tabular}{lc}
\hline Sumber : Data Diolah, 2019. & \\
\hline Tingkat Akurasi & $77.70 \%$ \\
Type I Error & $18.24 \%$ \\
Type II Error & $4.05 \%$ \\
Jumlah & $100.00 \%$ \\
\hline
\end{tabular}

Sumber : Data Diolah, 2019.

Berdasarkan tabel 5 diatas dapat

dilihat bahwa model Altman (Z-Score) menghasilkan tingkat akurasi sebesar $77,70 \%$ serta kesalahan prediksi type I sebesar $18,24 \%$ dan type II sebesar $4,05 \%$ dengan rincian perhitungan adalah sebagai berikut:

1. Tahun 2015 memprediksi dari 37 sampel perusahaan manufaktur sektor dasar dan kimia, jumlah prediksi benar (bangkrut) sebanyak 30 perusahaan, jumlah prediksi salah (tidak bangkrut) type I error sebanyak 7 perusahaan dan type II error sebanyak 0 perusahaan.

2. Tahun 2016 memprediksi dari 37 sampel perusahaan manufaktur sektor dasar dan kimia, jumlah prediksi benar (bangkrut) sebanyak 28 perusahaan, jumlah prediksi salah (tidak bangkrut) type I error sebanyak 7 perusahaan dan type II error sebanyak 2 perusahaan.
3. Tahun 2017 memprediksi dari 37 sampel perusahaan manufaktur sektor dasar dan kimia, jumlah prediksi benar (bangkrut) sebanyak 26 perusahaan, jumlah prediksi salah (tidak bangkrut) type I error sebanyak 8 perusahaan dan type II error sebanyak 3 perusahaan.

4. Tahun 2018 memprediksi dari 37 sampel perusahaan manufaktur sektor dasar dan kimia, jumlah prediksi benar (bangkrut) sebanyak 31 perusahaan, jumlah prediksi salah (tidak bangkrut) type I error sebanyak 5 perusahaan dan type II error sebanyak 1 perusahaan.

Tabel 6. Perhitungan Keakuratan Prediksi Model Zmijewski

\begin{tabular}{|c|c|c|c|}
\hline \multicolumn{4}{|c|}{ Hasil Prediksi } \\
\hline Tahun & $\begin{array}{l}\text { Type I } \\
\text { Error }\end{array}$ & $\begin{array}{l}\text { Type II } \\
\text { Error }\end{array}$ & Sampel \\
\hline 2015 & 3 & 5 & 37 \\
\hline 2016 & 3 & 5 & 37 \\
\hline 2017 & 2 & 4 & 37 \\
\hline 2018 & 3 & 5 & 37 \\
\hline Jumlah & 11 & 19 & 148 \\
\hline \multicolumn{4}{|c|}{ Sumber : Data Diolah, 2019.} \\
\hline \multicolumn{3}{|c|}{$\begin{array}{ll}\text { Tingkat Akurasi } & 79.73 \%\end{array}$} & \\
\hline Type I Error & \multicolumn{2}{|c|}{$7.43 \%$} & \\
\hline Type II Error & \multicolumn{2}{|c|}{$12.84 \%$} & \\
\hline Jumlah & \multicolumn{2}{|c|}{$100.00 \%$} & \\
\hline \multicolumn{4}{|c|}{$\begin{array}{rlll}\text { Sumber : Data Diolah, } 2019 . & & & \\
\text { Berdasarkan } \quad \text { tabel } 6 & \text { diatas }\end{array}$} \\
\hline \multicolumn{4}{|c|}{ diketahui bahwa model Zmijewski (X- } \\
\hline \multicolumn{4}{|c|}{$\begin{array}{l}\text { Score) menghasilkan tingkat akurasi } \\
\text { sebesar } 79,73 \% \text { serta kesalahan } \\
\text { prediksi type I sebesar } 7,43 \% \text { dan type }\end{array}$} \\
\hline \multicolumn{4}{|c|}{$\begin{array}{l}\text { II sebesar } 12,84 \% \text { dengan rincian } \\
\text { perhitungan adalah sebagai berikut: }\end{array}$} \\
\hline
\end{tabular}


1. Tahun 2015 memprediksi dari 37 sampel perusahaan manufaktur sektor dasar dan kimia, jumlah prediksi benar (bangkrut) sebanyak 29 perusahaan, jumlah prediksi salah (tidak bangkrut) type I error sebanyak 3 perusahaan dan type II error sebanyak 5 perusahaan.

2. Tahun 2016 memprediksi dari 37 sampel perusahaan manufaktur sektor dasar dan kimia, jumlah prediksi benar (bangkrut) sebanyak 39 perusahaan, jumlah prediksi salah (tidak bangkrut) type I error sebanyak 3 perusahaan dan type II error sebanyak 5 perusahaan.

3. Tahun 2017 memprediksi dari 37 sampel perusahaan manufaktur sektor dasar dan kimia, jumlah prediksi benar (bangkrut) sebanyak 31 perusahaan, jumlah prediksi salah (tidak bangkrut) type I error sebanyak 2 perusahaan dan type 4 error sebanyak 3 perusahaan.

4. Tahun 2018 memprediksi dari 37 sampel perusahaan manufaktur sektor dasar dan kimia, jumlah prediksi benar (bangkrut) sebanyak 29 perusahaan, jumlah prediksi salah (tidak bangkrut) type I error sebanyak 3 perusahaan dan type II error sebanyak 5 perusahaan.

Tabel 7. Perhitungan Keakuratan Prediksi Model Grover

\begin{tabular}{ccccc}
\hline \multirow{2}{*}{ Tahun } & \multicolumn{3}{c}{ Hasil Prediksi } & Sampel \\
& Benar & Type I & Type II & \\
\hline
\end{tabular}

\begin{tabular}{|c|c|c|c|c|}
\hline & & Error & Error & \\
\hline 2015 & 31 & 3 & 3 & 37 \\
\hline 2016 & 30 & 3 & 4 & 37 \\
\hline 2017 & 31 & 2 & 4 & 37 \\
\hline 2018 & 34 & 0 & 3 & 37 \\
\hline Jumlah & 126 & 8 & 14 & 148 \\
\hline \multicolumn{5}{|c|}{ Sumber : Data Diolah, 2019.} \\
\hline \multicolumn{2}{|c|}{ Tingkat Akurasi } & \multicolumn{2}{|r|}{$85.14 \%$} & \\
\hline \multicolumn{2}{|c|}{ Type I Error } & \multicolumn{2}{|r|}{$5.41 \%$} & \\
\hline \multicolumn{2}{|c|}{ Type II Error } & \multicolumn{2}{|r|}{$9.46 \%$} & \\
\hline \multicolumn{2}{|l|}{ Jumlah } & \multicolumn{2}{|r|}{$100.00 \%$} & \\
\hline
\end{tabular}

Berdasarkan tabel 7 diatas diketahui bahwa model Grover (GScore) menghasilkan tingkat akurasi sebesar $85,14 \%$ serta kesalahan prediksi type I sebesar 5,41\% dan type II sebesar $9,46 \%$ dengan rincian perhitungan adalah sebagai berikut:

1. Tahun 2015 memprediksi dari 37 sampel perusahaan manufaktur sektor dasar dan kimia, jumlah prediksi benar (bangkrut) sebanyak 31 perusahaan, jumlah prediksi salah (tidak bangkrut) type I error sebanyak 3 perusahaan dan type II error sebanyak 3 perusahaan.

2. Tahun 2016 memprediksi dari 37 sampel perusahaan manufaktur sektor dasar dan kimia, jumlah prediksi benar (bangkrut) sebanyak 30 perusahaan, jumlah prediksi salah (tidak bangkrut) type I error sebanyak 3 perusahaan dan type II error sebanyak 4 perusahaan.

3. Tahun 2017 memprediksi dari 37 sampel perusahaan manufaktur sektor dasar dan kimia, jumlah prediksi benar (bangkrut) sebanyak 31 
perusahaan, jumlah prediksi salah (tidak bangkrut) type I error sebanyak 2 perusahaan dan type II error sebanyak 4 perusahaan.

4. Tahun 2018 memprediksi dari 37 sampel perusahaan manufaktur sektor dasar dan kimia, jumlah prediksi benar (bangkrut) sebanyak $\quad 34$ perusahaan, jumlah prediksi salah (tidak bangkrut) type I error sebanyak 0 perusahaan dan type II error sebanyak 3 perusahaan.

\section{Tabel 8. Rekapitulasi Keakuratan}

\section{Prediksi}

\begin{tabular}{lccc}
\hline & \multicolumn{3}{c}{ MODEL PREDIKSI } \\
PERHITUNGAN & $\begin{array}{c}\text { KEBANGKRUTAN } \\
\text { Altman }\end{array}$ & $\begin{array}{c}\text { Zmijewski } \\
\text { (Z-Score) }\end{array}$ & $\begin{array}{c}\text { Grover } \\
\text { (X-Score) } \\
\text { (G-Score) }\end{array}$ \\
\hline $\begin{array}{l}\text { PREDIKSI } \\
\text { BENAR }\end{array}$ & 115 & 118 & 126 \\
\hline TYPE I ERROR & 27 & 11 & 8 \\
\hline TYPE II ERROR & 6 & 19 & 14 \\
\hline JUMLAH & 148 & 148 & 148 \\
SAMPEL & \multicolumn{1}{c}{} \\
\hline
\end{tabular}

Sumber : Data Diolah, 2019.

\begin{tabular}{lccc}
\hline & \multicolumn{3}{c}{ MODEL PREDIKSI } \\
PEBANGKRUTAN \\
& $\begin{array}{c}\text { Altman } \\
\text { (Z- } \\
\text { Score) }\end{array}$ & $\begin{array}{c}\text { Zmijewski } \\
\text { (X-Score) }\end{array}$ & $\begin{array}{c}\text { Grover } \\
\text { (G-Score) }\end{array}$ \\
\hline $\begin{array}{l}\text { TINGKAT } \\
\text { AKURASI }\end{array}$ & $77.70 \%$ & $79.73 \%$ & $85.14 \%$ \\
\hline TYPE I ERROR & $18.24 \%$ & $7.43 \%$ & $5.41 \%$ \\
\hline TYPE II ERROR & $4.05 \%$ & $12.84 \%$ & $9.46 \%$ \\
\hline JUMLAH & $100.00 \%$ & $100.00 \%$ & $100.00 \%$ \\
\hline
\end{tabular}

Sumber : Data Diolah, 2019.

Berdasarkan tabel 8 diatas

diketahui bahwa model Altman (ZScore) memprediksi dari 148 sampel perusahaan manufaktur sektor dasar dan kimia, jumlah prediksi benar (bangkrut) sebanyak 115 perusahaan, jumlah prediksi salah (tidak bangkrut) type I sebanyak 27 perusahaan dan type II sebanyak 6 perusahaan dan menghasilkan tingkat akurasi sebesar $77,70 \%$ serta kesalahan prediksi type I sebesar $18,24 \%$ dan type II sebesar $4,05 \%$.

Model Zmijewski (Z-Score) memprediksi dari 148 sampel perusahaan manufaktur sektor dasar dan kimia, jumlah prediksi benar (bangkrut) sebanyak 118 perusahaan, jumlah prediksi salah (tidak bangkrut) type I sebanyak 11 perusahaan dan type II sebanyak 19 perusahaan dan menghasilkan tingkat akurasi sebesar 79,73\% serta kesalahan prediksi type I sebesar $7,43 \%$ dan type II sebesar $9,46 \%$.

Model Grover (G-Score) memprediksi dari 148 sampel perusahaan manufaktur sektor dasar dan kimia, jumlah prediksi benar (bangkrut) sebanyak 126 perusahaan, jumlah prediksi salah (tidak bangkrut) type I sebanyak 8 perusahaan dan type II sebanyak 14 perusahaan dan menghasilkan tingkat akurasi sebesar $85,14 \%$ serta kesalahan prediksi type I sebesar $5,41 \%$ dan type II sebesar 12,84\%.

Hasil perbandingan ketiga model menunjukkan bahwa model Grover (G-Score) merupakan model prediksi kebangkrutan paling akurat dengan tingkat akurasi mencapai $85,14 \%$ dan tingkat error dalam kesalahan prediksi paling kecil yaitu type I error sebesar $5,41 \%$ dan type II error sebesar $12,84 \%$. Sedangkan kedua model lainnya yaitu model Altman (ZScore) dan model Zmijewski (X-Score) tidak akurat karena tingkat error (kesalahan model dalam memprediksi kebangkrutan) lebih besar dari tingkat akurasi.

\section{KESIMPULAN DAN SARAN \\ Kesimpulan}

Berdasarkan hasil analisis dan uji hipotesa menunjukkan bahwa terdapat 
perbedaan antara model Altman, Zmijewski dan Grover dalam memprediksi kebangkrutan (financial distress) pada perusahaan manufaktur sektor industri dasar dan kimia yang terdaftar di Bursa Efek Indonesia periode 2015-2018. Model Grover (G-Score) merupakan model yang paling akurat untuk memprediksi kebangkrutan (financial distress) dengan tingkat akurasi mencapai $85,14 \%$. Melalui Model Grover (G-Score) diketahui bahwa perusahaan yang berpotensi mengalami kebangkrutan (financial distress) adalah ALMI (20152016), APLI (2018), BAJA (2017-2018), CPRO (2015-2018), GDST (2015 dan 2018), KBRI (2015-2018), SMCB (20152018), ALKA (2016), FASW (2015), MAIN (2017), SIPD (2015-2017), SPMA (2016) dan WSBP (2015).

\section{Saran}

1. Untuk investor sebelum berinvestasi sebaiknya melakukan prediksi financial distress menggunakan model prediksi untuk mengurangi tingkat risiko kesalahan pemilihan perusahaan yang diperkirakan memiliki kinerja keuangan yang baik namun ternyata buruk. Terdapat beberapa model prediksi yang bisa dijadikan pilihan seperti model Altman, Zmijewski dan Grover.

2. Untuk manajemen segera mendeteksi sejak dini indikasi terjadinya kesulitan keuangan yang berdampak pada kebangkrutan (financial distress). Selanjutnya menghindari potensi saham yang dihapus dari BEI dengan tindakan tertentu seperti melakukan penghitungan prediksi financial distress menggunakan model Altman, Zmijewski. dan Grover.

3. Untuk peneliti selanjutnya bisa menambahkan model prediksi lainnya seperti Model Ohlson, Model Taffler, Model Shirata, Model Fulmer, Model Springate, Model CA-Score, Model Zavgren dll.

\section{DAFTAR PUSTAKA}

Alali, M. S., Alawadhi, A. M., \& Bash, A. Y. (2018). Predicting Bankruptcy Risk For Healthcare Companies Listed In Kuwait Stock Exchange Using Altman's Z-Score Model. Eureka, 2581, 4249.

Alali, M. S., Bash, A. Y., Alforaih, E. O., Alsabah, A. M., \& Alsalem, A. S. (2018). The Adaptation Of Zmijewski Model In Appraising The Financial Distress Of Mobile Telecommunications Companies Listed At Boursa Kuwait. Management, 5(4), 129-136.

Ambarwati, U., Sudarwati, S., \& Widayanti, R. (2017). Analisis Financial Distress Pada Pt Tunas Baru Lampung Tbk Di Bursa Efek Indonesia. Jurnal Organisasi Dan Manajemen, 13(2), 129-141.

Basoda, M., \& Celik, A. (2018). Konkursprognostisering: $\quad$ En Studie Om Nyckeltalens Betydelse Vid Konkurser I De Svenska ByggföRetagen.

Cheng, C. H., Chan, C. P., \& Yang, J. H. (2018). A Seasonal Time-Series Model Based On Gene Expression Programming For Predicting Financial Distress. Computational Intelligence And Neuroscience, 2018.

Dp, E. N., \& Wulandari, V. Analisis Perbandingan Model Altman, Springate, Ohlson, Fulmer, CAScore Dan Zmijewski Dalam 
Memprediksi Financial Distress (Studi Empiris Pada Perusahaan Food And Beverages Yang Terdaftar Di Bursa Efek Indonesia Periode 2010-2012). Jurnal Online Mahasiswa Fakultas Ekonomi Universitas Riau, 1(2).

Ghosh, B. (2017). Bankruptcy Modelling Of Indian Public Sector Banks: Evidence From Neural Trace. International Journal Of Applied Behavioral Economics (Ijabe), 6(2), 52-65.

Ghozali, I. (2016). Aplikasi Analisis Multivariete Dengan Program IBM SPSS 23, Edisi Delapan. Semarang: Penerbit Universitas Diponogoro.

Kartikasari (2018). Analilis Prediksi Financial Distress Dengan Model Ohlson, Model Fulmer, Model CAScore Dan Model Zavgren (Studi Kasus Pada Perusahaan Ritel Yang Terdaftar Di Bursa Efek Indonesia Tahun 2015-2018). Skripsi Tidak Diterbitkan. Madiun: Program Studi Akuntansi Fakultas Ekonomi Dan Bisnis Universitas Pgri Madiun.

Koh, A., Ang, S. K., Brigham, E. F., \& Ehrhardt, M. C. (2014). Financial Management: Theory And Practice. Cengage Learning.

Manousaridis, C. O. (2017). Z-Altman's Model Effectiveness In Bank Failure Prediction-The Case Of European Banks.

Meiliawati, A., \& Isharijadi, I. (2017). Analisis Perbandingan Model Springate Dan Altman Z Score Terhadap Potensi Financial Distress (Studi Kasus Pada Perusahaan Sektor Kosmetik Yang Terdaftar Di Bursa Efek Indonesia). Assets: Jurnal
Akuntansi Dan Pendidikan, 5(1), 15-24.

Odibi, I., Basit, A., \& Hassan, Z. (2015). Bankruptcy Prediction Using Altman Z-Score Model: A Case Of Public Listed Manufacturing Companies In Malaysia. International Journal of Accounting \& Business Management, 3(2), 178-186.

Peter, P., \& Yoseph, Y. (2011). Analisis Kebangkrutan Dengan Metode ZScore Altman, Springate Dan Zmijewski Pada PT. Indofood Sukses Makmur Tbk Periode 2005-2009. Maksi, 4(2).

Prihanthini, N. M. E. D., \& Sari, M. M. R. (2013). Prediksi Kebangkrutan Dengan Model Grover, Altman ZScore, Springate Dan Zmijewski Pada Perusahaan Food And Beverage Di Bursa Efek Indonesia. E-Jurnal Akuntansi, 417-435.

Subramanyam, K. R., \& Wild, J. J. (2014). Analisis Laporan Keuangan. Jakarta: Salemba Empat.

Sugiyono. (2016). Metode Penelitian Kuantitatif, Kualitatif, Dan R\&D. Bandung: CV Alfabeta.

Tuvadaratragool, S. (2013). The Role Of Financial Ratios In Signalling Financial Distress: Evidence From Thai Listed Companies.

Widiyawati, A. T., Utomo, S. W., \& Amah, N. (2015). Analisis Rasio Altman Modifikasi Pada Prediksi Kebangkrutan Perusahaan Property Dan Real Estate Yang Terdaftar Di BEI. Assets: Jurnal Akuntansi Dan Pendidikan, 4(2), 112-124.

www.cnnindonesia.co.id www.idx.co.id 
